\title{
Pelatihan Pembuatan PKM ke Kemenristekdikti
}

\author{
HARDI $^{1}$, NURHAYANI LUBIS ${ }^{2}$, GUSMARILA EKA PUTRI $^{3}$ \\ 1,2,3 Universitas Lancang Kuning \\ Jln. Yos Sudarso KM 08 Rumbai Telp. (0761) 52581 \\ E-mail : hardi@unilak.ac.id
}

\begin{abstract}
The main problem with the inactivity of the Student Creativity Program in the Presence of the Riau Malay Arts Academy (AKMR) is the ignorance and motivation of students from the service group and information is not maximal in the proposal writing to be sent to the Ministry of Research and Technology. The prospect of students in the seminars of the World Health Program is going through Riau through the discovery of ideas and ideas to make proposals for the Student Creativity Program very well. After getting the direction and material presented by the motivator and the dedication team, the understanding and motivation in making entrepreneurship proposals for students increased. Can be seen after the question and answer that students have understood and motivated in making the PKM-K Proposal which will be submitted to the Ministry of Research and Technology and also as a reference to open a business after graduating from college. Can be seen from the results of the questionnaire after giving the material and explanation regarding the making of the PKM-K proposal, all $100 \%$ statements were answered correctly by the students.
\end{abstract}

Keywords: Motivation, Knowledge Enhancement, Creativity

Kehadiran Akademi Kesenian Melayu Riau (AKMR) ditengah-tengah masyarakat Riau membuat yang sedang membutuhkan pendidikan tinggi dibidang seni melalui saluran berbagai media komunikasi massa seperti televisi, radio, surat kabar, dan majalah. Di daerah Riau AKMR satusatunya Akademi yang yang pendidikannya mengarahkan mahasiswanya untuk bisa terampil dalam berkesenian, masyarakat dan pemerintah kabupaten dan kota membatu memberikan beasiswa untuk masysarakat yang ingin melanjutkan kuliah di AKMR.

Pada saat ini Akademi Kesenian Melayu Riau (AKMR) telah berdiri kukuh dan sejajar serta turut berpacu dengan perguruan tinggi seni lain di tanah air. AKMR memiliki mahasiswa pada Program Studi Seni Tari, Seni Musik, dan Seni Teater. Sarana dan prasarana tahap demi tahap telah dipenuhi. Perpustakaan, laboratorium, Studio Musik, Tari, dan Teater, workshop telah dibangun tahap demi tahap. Semuanya ini dimaksudkan dalam rangka meningkatkan kualitas para lulusan. Perkembangan ekonomi, pembangunan dan politik di tanah air dan Riau khususnya telah pula turut mewarnai perjalanan perguruan tinggi ini.

Keberhasilan peserta didik dalam belajar tergantung dari bagaimana sikap mereka dalam menggunakan waktu luangnya untuk belajar. Namun aktivitas yang dilakukan oleh mereka di waktu luang tidak hanya digunakan untuk belajar, namun banyak mahasiswa yang memanfaatkan waktu luangnya untuk halhal yang kurang efektif. Namun ada beberapa mahasiswa yang menggunakan waktu luangnya untuk kegiatan yang efektif serta dapat menghasilkan keuntungan bagi dirinya seperti dengan membuka sebuah usaha atau berwirausaha. Program Kreativitas Mahasiswa (PKM) merupakan suatu kebijakan yang dikeluarkan oleh Direktorat Jendral Pendidikan Tinggi (DIKTI) dalam rangka menyempurnakan program DIKTI sebelumnya yaitu KAM (Karya Alternatif Mahasiswa).

Motivasi merupakan faktor yang sangat berpengaruh pada diri seseorang untuk menentukan apa yang menjadi 
keinginan dan usahanya untuk mewujudkan keinginannya tersebut. Menurut Uno (2008:1), "Motivasi adalah dorongan dasar yang menggerakkan seseorang bertingkah laku. Dorongan ini berada pada diri seseorang yang menggerakkan untuk melakukan sesuatu yang sesuai dengan dorongan dalam dirinya". Jadi, semakin besar motivasi yang dimiliki seseorang, maka akan semakin besar pula usaha untuk mewujudkan tujuannya.

AKMR belum memiliki peran dan terlibat secara aktif dalam pengembangan Program Kreatifitas Mahasiswa (PKM) Ristekdikiti. Terdapat tiga Program studi, berkaitan dengan Usulan proposal PKM mahasiswa yang berada di AKMR sampai tahun 2018 belum mengetahui berkaitan dengan PKM, Motivasi menjadi permasalahan yang menyebabkan belum adanya mahasiswa yang menulis Proposal PKM yang diajukan ke Ristekdikti.

Motivasi mahasiswa AKMR dalam mengusulkan atau mengajukan proposal PKM karena tidak pahamnya dalam sistematika penulisan dan belum dijelaskan dari kampusnya dan kemungkinan juga disebabkan oleh beberapa faktor baik dari dalam diri mahasiswa maupun lingkungan sekitar. PKM merupakan suatu program yang diharapkan dapat meningkatkan daya saing mahasiswa yang berkualitas. Mahasiswa yang memiliki motivasi yang tinggi akan memanfaatkan kesempatan ini dalam bentuk partisipasi dalam pengajuan proposal PKM. Sedangkan mahasiswa yang memiliki motivasi yang rendah cenderung tidak ikut berpartisipasi dengan berbagai alasan.

Motivasi adalah suatu dorongan dari dalam diri seseorang yang mendorong orang tersebut untuk me-lakukan sesuatu, termasuk menjadi young entrepre-neur (Sarosa, 2005). Kebanyakan orang yang berhasil di dunia ini mempunyai motivasi yang kuat yang mendorong tindakantindakan mereka. Mereka me-ngetahui dengan baik yang menjadi motivasinya dan memelihara motivasi tersebut dalam setiap tindakan-nya. Baum, Frese, and Baron
(2007) menjelaskan bahwa motivasi dalam kewirausahaan meliputi moti-vasi yang diarahkan untuk mencapai tujuan kewira-usahaan, seperti tujuan yang melibatkan pengenalan dan eksploitasi terhadap peluang bisnis. Motivasi un-tuk mengembangkan usaha baru diperlukan bukan hanya oleh rasa percaya diri dalam hal kemampuan-nya untuk berhasil, namun juga oleh kemampuannya dalam mengakses informasi mengenai peluang kewirausahaan.

\section{METODE}

Naskah ini disusun dengan menggunakan metode deskriptif yang menggambarkan kondisi real lapangan. Suroto, (2017).

Menggunakan metode pelatihan yang diberikan kepada peserta dan data dianalisis dengan menggunakan pre test dan post test hasil pelatihan dan dianalisis secara deskriptif.

\section{HASIL}

Pelaksanaan kegiatan pengabdian kepada masyarakat di Akademi Kesenian Melayu Riau. Kegiatan pengabdian ini dilaksanakan pada bulan Nopember s/d Januari 2018. Para peserta yang hadir pada waktu pelaksanaan kegiatan ini adalah kelompok Mahasiswa Program studi Tari dan Musik Akademi kesenian Melayu Riau.

Adapun peserta mahasiswa yang telah ikut serta dalam kegiatan pemagangan, dari peserta yang kita harapkan sekitar 14 orang dari mitra kelompok pengabdian dari Mahasiswa Akademi Kesenian Melayu Riau. Dari harapan tersebut ternyata pesertanya yang datang sebanyak 10 orang yang bisa mengikuti kegiatan Pengabdian Kepada Masyarakat tersebut.

Dari hasil ceramah, diskusi, tanya jawab, kami dapat menyimpulkan bahwa peserta sebagian besar belum mendapatkan informasi terkait program Kreativitas Mahasiswa (PKM) dari Kemenristekdikti dan motivasi untuk lebih baik sebaga mahasiswa dikarenakan kurangnya 
informasi dan pemahaman akan pentingnya dari program tersebut. hal ini dapat dilihat dari hasil kuisioner sebelum dan sesudah mendapat pembekalan dan materi tentang pemahaman tentang pelatihan pembiatan Proposal program Kreativitas Mahasiswa (PKM).

Pada akhir sesi dari pengabdian masyarakat ini, para peserta pengabdian mulai memahami apa pelatihan pembuatan Proposal program kreativitas mahasiwa (PKM) yang merupakan program yang sangat bermanfaat bagi mahasiswa sebelum menamatkan kuliah, tentang motivasi dari program terebut yang akan mendapatkan dana bantuan untuk melaksanakan kewirausahaan sambil kuliah., mahasiwa sudah dapat menatap masa depan lebih baik dengan program yang dibiayai oleh kemenristekdikti ditjen Belmawa. Yang perlu kami tekankan disini, bahwa dengan program kreativitas mahasiwa (PKM) bisa mendapatkan pengalaman tambahan dengan memanfaatkan waktu luang sambil melaksanakan kewirausahaan selama 3 bulan dalam membuat dproduk dan melaksanakan penjulan hasil dari produk tersebut. Dalam melaksanakan kegiatan PKM Kewirausahaan akan dibimbing oleh dosen pendamping sampai dengan sukses melaksanakan kegiatan PKM kewirausahaan sehingga bisa memotivasi mahasiswa untuk membuka usaha sendiri secara mandiri.

\section{PEMBAHASAN}

Peningkatan motivasi mahasiswa dalam program belajar bekerja terpadu di lingkungan Universitas Lancang Kuning adalah merupakan bagian yang sangat penting dan harus diketahui oleh para mahasiswa untuk menuju tidak sulitnya untuk mencarai pekerjaan setealh tamat dari universitas lancang kuning agar mahasiswa lebih berinovasi dan kreatifitas dalam menghadapi tantangan di era Masyarakat Ekonomi Asean. Keterbatasan dalam mencari informasi tentang Program belajar bekerja terpadu dalam peningkatan pemahaman dan motivasi berwirausaha memang tidak mudah untuk dilaksanakan oleh mahasiswa mitra pengabdian. pemahaman motivasi mahasiswa dalam Program Belajar bekerja teraodu akan membentuk pola pikir mahasiswa dalam meningkatkan daya kreatifitas dan inovasi dalam merancang dan merintis usaha sejak usia dini ini, sehingga dapat bersaing dengan yang lainnya.

Dalam kegiatan pengabdian masyarakat ini dengan cara menyebarkan quisioner sebelum dan sesudah pelaksanaan pelaksanaan pengabdian. Adapun untuk mengetahui motivasi mahasiswa dalam Program Belajar Bekerja Terpadu di Universitas Lancang Kuning, dapat dilihat dari pertanyaan yang telah dijawab sebagai berikut:

Tabel 1: Tanggapan responden tentang Pelatihan Pembuatan PKM ke Kemenristekdikti

\begin{tabular}{|c|c|c|c|c|c|c|c|}
\hline \multirow{2}{*}{ No } & \multirow{2}{*}{ Pertanyaan } & \multicolumn{3}{|c|}{ Sebelum } & \multicolumn{3}{|c|}{ Sesudah } \\
\hline & & YA & TIDAK & $\%$ & YA & TIDAK & $\%$ \\
\hline 1 & $\begin{array}{l}\text { Apakah sauadara merasa } \\
\text { butuh akan informasi } \\
\text { mengenai program PKM? }\end{array}$ & 8 & 2 & 80 & 10 & 0 & 100 \\
\hline 2 & $\begin{array}{l}\text { Apakah saudara tahu } \\
\text { Program Produk Kreatifitas } \\
\text { Mahasiswa dari Dikti? }\end{array}$ & 4 & 6 & 40 & 10 & 0 & 100 \\
\hline 3 & $\begin{array}{lr}\text { Apakah } & \text { saudara } \\
\text { mendapatkan } & \text { informasi } \\
\text { mengenai PKM? } & \end{array}$ & 7 & 3 & 70 & 10 & 0 & 100 \\
\hline 4 & $\begin{array}{l}\text { Apakah saudara termotivasi } \\
\text { dengan adanya program } \\
\text { PKM? }\end{array}$ & 7 & 3 & 70 & 10 & 0 & 100 \\
\hline 5 & $\begin{array}{lrr}\text { Apakah saudara mudah } \\
\text { dalam } & \text { mendapatkan } \\
\text { informasi terkait PKM ? }\end{array}$ & 6 & 4 & 60 & 10 & 0 & 100 \\
\hline 6 & $\begin{array}{l}\text { Apakah saudara tahu syarat- } \\
\text { syarat megikuti PKM? }\end{array}$ & 4 & 6 & 40 & 10 & 0 & 100 \\
\hline 7 & $\begin{array}{l}\text { Apakah saudara yakin bisa } \\
\text { membuat Proposal PKM? }\end{array}$ & 6 & 4 & 60 & 10 & 0 & 100 \\
\hline 8 & $\begin{array}{l}\text { Apakah saudara tahu } \\
\text { disiplin merupakan kunci } \\
\text { sukses dalam membuat } \\
\text { Proposal PKM? }\end{array}$ & 7 & 3 & 70 & 10 & 0 & 100 \\
\hline 9 & $\begin{array}{l}\text { Apakah saudara mengerti } \\
\text { dan bisa termotivasi dalam } \\
\text { membuat Proposak PKM } \\
\text { kewirausahaan? }\end{array}$ & 8 & 2 & 80 & 10 & 0 & 100 \\
\hline $\begin{array}{l}1 \\
0\end{array}$ & $\begin{array}{lcr}\text { Apakah saudara } & \text { tahu } \\
\text { jumlah wirausaha } & \text { di } \\
\text { Indonesia lebih sedikit dari } \\
\text { negara tetangga? }\end{array}$ & 5 & 5 & 50 & 10 & 0 & 100 \\
\hline
\end{tabular}

Sumber: Hasil Olahan Data Kuesioner

Berdasarkan tabel diatas terlihat sebenarnya peserta sudah mengetahui bagaimana tentang Program Kreativitas Mahsiswa (PKM) dan bisa memahami bagaimana motivasi dalam pembuatan proposal PKM-K tersebut. Akan tetapi mahasiswa belum begitu memahami tata cara dalam pembuatan proposal dan berpartisipasi aktif dikarenakan pemahaman dan informasi yang kurang memadai terkait program kreatifitas mahssiwa 
(PKM-K) yang setiap tahunnya ada dan diumumkan secara menyeluruh ke setiap Universitas dan Akdemi seluruh Indonesia.

Setelah mendapat arahan dan materi yang disampaikan oleh motivator dan tim pengabdian terlihat pemahaman dan motivasi dalam pembuatan proposal kewirausahaan para mahasiswa meningkat. Dari tabel diatas terlihat bahwa mahasiswa sudah memahami dan termotivasi dalam membuat Proposal PKM-K yang akan diajukan ke kemenritek di dan juga sebagai referensi untuk membuka usaha setealh tamat dari bangku kuliah. Dapat dilihat dari hasil kuesioner setelah diberinya materi dan penjelasan terkait pembuatan Proposal PKM-K, semua pernyataan $100 \%$ dijawab benar oleh mahasiswa.

Secara keseluruhan pelaksanaan pengabdian berhasil karena peserta mampu menguasai materi yang diberikan, baik dari dari segi pemahaman dan juga termotivasi untuk ikut dalam pembuatan proposal PKM$\mathrm{K}$ lebih dari $75 \%$ sesuai yang ditargetkan.

Dengan diadakan sosialisasi dan penyuluhan motivasi tentang program PKM$\mathrm{K}$ pemahaman dan motivasi mahasiswa dalam ikut program tersebut memperoleh hasil dan manfaat, terutama bagi mahasiswa Akademi Kesenian Melayu Riau (AKMR). Tim mampu memberikan pengetahuan baru untuk mahasiswa yang disampaikan oleh Tim Dosen mampu melaksanakan tri dharma perguruan tinggi yaitu pengabdian kepada masyarakat dengan terlaksananya kegiatan ini.

\section{SIMPULAN}

Pada tahap awalnya sebelum pemberian pembekalan pembuatan proposal PKM-K dan memotivasi mahasiswa dalam Program pembutan Proposal PKM-K, pengabdian masyarakat ini diikuti 10 mahasiswa, mahasiswa Akademi Kesenian Melayu Riau.

Para peserta sebelum diadakan pembekalan tentang motivasi dan pembuatan Proposal PKM-K dalam program kreativitas mahasiswa (PKM), banyak yang belum memahami dan termotivasi untuk bisa ikut pada program tersebut. Dan setelah dilakukan sosialiasai dan pembekalan tentang motivasi dan cara pembuatan proposal PKM-K dalam Program kreativitas mahsiswa, mereka mulai memahami meskipun belum semuanya bisa ikut dalam kegiatan tersebut.

Kami sebagai Tim menyarankan kepada para mahasiswa agar mereka memulai usaha untuk sering melakukan mencari informasi terkait program-program yang bisa mereka ikuti untuk menambah wawasan terkait Program Kreativitas Mahasiwa (PKM).

Alokasi waktu penyelenggaraan perlu ditambah terutama untuk sesi diskusi agar lebih banyak waktu menyampaikan beberapa masalah-masalah yang dihadapi oleh mahasiswa.

\section{DAFTAR RUJUKAN}

Sarosa, P. (2005). Kiat praktis membuka usaha. Be-coming young entrepreneur: Dream big start small, act now! Panduan praktis \& motivasional bagi kaum muda dan mahasiswa. Jakarta: PT Elex Media Komputindo.

Suroto, B., Novita, N., Pailis, E. A., Waldelmi, I., \& Fatkhurahman, F. (2017). Metode Penelitian Tindakan Solusi Bagi Masalah Sosial. Jurnal Diklat Review, 1(1), 25-28.

Uno, Hamzah. 2008. Teori Motivasi \& Pengukurannya Analisis Dibidang Pendidikan. Jakarta. Bumi Aksara. 